\title{
The Empirical Review of Several Hypotheses of the Emotional Maturation of Teenage Students at the Secondary School ,28 November " in Prishtina with the Assistance of Chi-Squared Test
}

\author{
Nerxhivane Krasniqi \\ Secondary School,,28 November" Prishtina-Kosova \\ nexha61@gmail.com
}

Doi:10.5901/ajis.2015.v4n1s2p135

\section{Abstract}

This paper presents the empirical analysis of several hypotheses of the emotional maturation of teenage students with no parametric statistical method such as chi-squared test. The following hypotheses have been analyzed using this method: There is a positive influence as regards the emotional maturation and achievement of success by students while studying; -The emotional maturation of adult students depends on their age; -The emotional maturation of adult students depends on their gender. - The emotional maturation and the success of the adolescent students depend on the age and gender of the adolescent respondents who have been researched. This empirical analysis covered a sample of 200 students, out of them , 100 students belonged to the 10th class while 100 students belonged to the 13th class at the Technical Secondary School "28 November" in Prishtina. Out of these students, half of them were males and half of them were females.

Keywords: Emotional, maturation, students

\section{The analysis of the veracity of the hypotheses by chi-squared test $\left(\chi^{2}\right)$}

Using this statistical method, which is called non-parametric statistics, we manipulate with qualitative facts as follows: Yes-No; Young, Old; Healthy, Sick etc. and we do not manipulate with quantitative measured facts such as the number of obtained points, kilograms etc. If the value of chi-square is zero, this means that there is no difference between the empirical and theoretical frequencies. If the chi-square is closer to zero then there are more probabilities to accept the hypothesis and the opposite, if the chi-square is away from zero then there are more probabilities to reject the hypothesis because there is a big difference between the empirical and theoretical frequencies.

We will use this statistical method to analyze the veracity of several hypotheses of the emotional maturation. One of key hypotheses of the emotional maturation is:

"The emotional maturity is an indicator that adolescent students have achieved good success at school"

In relation to this hypothesis, we have taken group samples of answers for all 200 students (100 students of the $10^{\text {th }}$ class and 100 students of the 13 $13^{\text {th }}$ class) at the Technical Secondary School "28 November" in Prishtina. The questionnaire and its analysis have been made in June 2011. From these samples have been taken empiric frequencies and as regards the veracity of the hypothesis it resulted that: $f_{\text {empiric }}=f_{\mathrm{e}}=82$, were in support of this hypothesis, it means a positive answer (YES) for the abovementioned hypothesis, 61 were not in support of the hypothesis, it means a negative answer (NO) while 57 students were in support of the option of the questionnaire (I DON'T KNOW) related to this hypothesis. The theoretical frequency $f_{t}$ for the sample covering 200 students, taking into consideration that we have three options to be selected, is $\mathrm{f}_{\text {theoretical }}=\mathrm{f}_{\mathrm{t}}=200: 3=66$. From the second and third row we find the difference between the second column and third column and we put the achieved result in a special column ( $\left.\mathrm{f}_{e}-\mathrm{f}_{\mathrm{t}}\right)$. Then this value is squared and the same one is put in a special row $\left(\mathrm{f}_{\mathrm{e}}-\mathrm{f}_{\mathrm{t}}\right)^{2}$. The obtained value is divided by the empiric frequency and the values of the obtained ratio $\left(\mathrm{f}_{\mathrm{e}}-\mathrm{f}_{\mathrm{t}}\right)^{2} / \mathrm{f}_{\mathrm{t}}$ are put in a special row.

In order to implement chi-squared test $\left(\chi^{2}\right)$ we prepare the table of frequencies 
Table 1

\begin{tabular}{|c|c|c|c|c|c|}
\cline { 2 - 5 } \multicolumn{1}{c|}{} & $\mathrm{fe}_{\mathrm{e}}$ & $\mathrm{f}_{\mathrm{t}}$ & $\mathrm{f}_{\mathrm{e}}-\mathrm{f}_{\mathrm{t}}$ & $\left(\mathrm{f}_{\mathrm{e}}-\mathrm{f}_{\mathrm{t}}\right)^{2}$ & $\left(\mathrm{f}_{\mathrm{e}}-\mathrm{f}_{\mathrm{t}}\right)^{2} / \mathrm{f}_{\mathrm{t}}$ \\
\hline YES & 82 & 66 & 16 & 256 & 3.87 \\
\hline NO & 61 & 66 & -5 & 25 & 0.378 \\
\hline I DON'T KNOW & 57 & 66 & -9 & 81 & 1.227 \\
\hline
\end{tabular}

In order to find the value of $\left(\chi^{2}\right)$, we add the results obtained in the last row as follows:

\section{$\chi^{2}=3.87+0.378+1.227=5.475$}

The questionnaire which was used to analyze the veracity of the key hypothesis and presented sub-hypotheses, has three options (YES, NO and I DON'T KNOW). This means that we should know two quantities in order to determine the third quantity. Thus, our problem has two freeing scales with a probability level under $5 \%$, what it means that for the accuracy of $95 \%$, on the table it is read the value of chi-square $\chi^{2}=5.991$ while for the level of importance, under $1 \%$, of the probability level, the value is $\chi^{2}=9.210$.

Since the fixed value of our chi-square $\chi^{2}=5.475$ is smaller than the standard value of $\chi^{2}$ which for the freeing scale 2 is $\chi^{2}=5.991$, it comes out that the presented hypothesis has been verified. This hypothesis is verified, also, for the level of importance $1 \%=0.01$ since for the freeing scale 2 the standard value of $\chi^{2}$ is 9.210 which is bigger than our chsquare 5.475 .

\section{The Analysis of the Veracity of the Sub-Hypotheses by Chi-Squared Test $\left(\chi^{2}\right)$}

The analysis of sub-hypothesis H1: The emotional maturation depends on the age of adolescent students"

Table 2

\begin{tabular}{|c|c|c|c|c|c|}
\cline { 2 - 5 } \multicolumn{1}{c|}{} & $\mathrm{fe}_{\mathrm{e}}$ & $\mathrm{f}_{\mathrm{t}}$ & $\mathrm{f}_{\mathrm{e}}-\mathrm{f}_{\mathrm{t}}$ & $\left(\mathrm{f}_{\mathrm{e}}-\mathrm{f}_{\mathrm{t}}\right)^{2}$ & $\left(\mathrm{f}_{\mathrm{e}}-\mathrm{f}_{\mathrm{t}}\right)^{2} / \mathrm{f}_{\mathrm{t}}$ \\
\hline YES & 60 & 66 & -6 & 36 & 0.54 \\
\hline NO & 65 & 66 & -1 & 1 & 0.015 \\
\hline I DON'T KNOW & 75 & 66 & 9 & 81 & 0.27 \\
\hline
\end{tabular}

In order to find the value of $\left(\chi^{2}\right)$, we add the results obtained in the last row as follows:

$\chi^{2}=0.54+0.015+0.27=0.827$.

Since the value of $\chi^{2}=0.827$, it means that it is smaller than the standard value of $\chi^{2}$ which for the freeing scale 2 is $\chi^{2}=5.991$, it comes out that the presented sub-hypothesis has been verified. This sub-hypothesis is verified, also, for the level of importance $1 \%=0.01$ since for the freeing scale 2 the standard value of $\chi^{2}$ is 9.210 .

The analysis of sub-hypothesis $\mathrm{H} 2$ : The emotional maturation depends on the gender of adolescent students

Table 3

\begin{tabular}{|c|c|c|c|c|c|}
\cline { 2 - 5 } \multicolumn{1}{c|}{} & $\mathrm{f}_{\mathrm{e}}$ & $\mathrm{f}_{\mathrm{t}}$ & $\mathrm{f}_{\mathrm{e}}-\mathrm{f}_{\mathrm{t}}$ & $\left(\mathrm{f}_{\mathrm{e}}-\mathrm{f}_{\mathrm{t}}\right)^{2}$ & $\left(\mathrm{f}_{\mathrm{e}}-\mathrm{f}_{\mathrm{t}}\right)^{2} / \mathrm{f}_{\mathrm{t}}$ \\
\hline YES & 75 & 66 & 9 & 81 & 1.27 \\
\hline NO & 90 & 66 & 24 & 376 & 5.69 \\
\hline I DON'T KNOW & 35 & 66 & 31 & 961 & 14.5 \\
\hline
\end{tabular}

In order to find the value of $\left(\chi^{2}\right)$, we add the results obtained in the last row as follows: $\chi^{2}=1.27+5.69+14.5=21.46$

Since the value of $\chi^{2}=21.46$, it means that it is bigger than the standard value of $\chi^{2}$ which for the freeing scale 2 is $\chi^{2}=5.991$, it comes out that the presented sub-hypothesis hasn't been verified. This sub-hypothesis is rejected, also, for the level of importance $0.99 \%$ since for the freeing scale 2 the standard value of $\chi^{2}$ is 9.210 . This hypothesis is rejected since the received answers from this representative group do have differences of statistical importance compared with those we have expected.

The analysis of sub-hypothesis H3: There is a positive impact as regards emotional maturation and achievement of success at school 
Table 4

\begin{tabular}{|c|c|c|c|c|c|}
\cline { 2 - 5 } \multicolumn{1}{c|}{} & $\mathrm{f}_{\mathrm{e}}$ & $\mathrm{f}_{\mathrm{t}}$ & $\mathrm{f}_{\mathrm{e}}-\mathrm{f}_{\mathrm{t}}$ & $\left(\mathrm{f}_{\mathrm{e}}-\mathrm{f}_{\mathrm{t}}\right)^{2}$ & $\left(\mathrm{f}_{\mathrm{e}}-\mathrm{f}_{\mathrm{t}}\right)^{2} / \mathrm{f}_{\mathrm{t}}$ \\
\hline YES & 71 & 66 & 5 & 25 & 0.37 \\
\hline NO & 62 & 66 & -4 & 16 & 0.24 \\
\hline I DON'T KNOW & 67 & 66 & 3 & 9 & 0.13 \\
\hline
\end{tabular}

In order to find the value of $\left(\chi^{2}\right)$, we add the results obtained in the last row as follows:

$\chi^{2}=0.37+0.24+0.13=0.74$.

Since the value of $\chi^{2}=0.74$, it means that it is smaller than the standard value of $\chi^{2}$ which for the freeing scale 2 is $\chi^{2}=5.991$, it comes out that the presented sub-hypothesis has been verified. This sub-hypothesis is verified, also, for the level of importance $1 \%=0.01$ since for the freeing scale 2 the standard value of $\chi^{2}=9.210$.

Hypothesis $\mathrm{H} 4$ : The emotional maturation and the success of the adolescent students depend on the age and gender of the adolescent respondents who have been researched

\section{Table 5}

\begin{tabular}{|c|c|c|c|c|c|}
\cline { 2 - 5 } \multicolumn{1}{c|}{} & $\mathrm{f}_{\mathrm{e}}$ & $\mathrm{f}_{\mathrm{t}}$ & $\mathrm{f}_{\mathrm{e}}-\mathrm{f}_{\mathrm{t}}$ & $\left(\mathrm{f}_{\mathrm{e}}-\mathrm{f}_{\mathrm{t}}\right)^{2}$ & $\left(\mathrm{f}_{\mathrm{e}}-\mathrm{f}_{\mathrm{t}}\right)^{2} / \mathrm{f}_{\mathrm{t}}$ \\
\hline YES & 74 & 66 & 8 & 64 & 0.96 \\
\hline NO & 67 & 66 & 3 & 9 & 0.136 \\
\hline I DON'T KNOW & 59 & 66 & -7 & 49 & 0.74 \\
\hline
\end{tabular}

$\chi^{2}=0.96+0.136+0.74=1.836$.

Since the value of $\chi^{2}=1.836$, it means that it is smaller than the standard value of $\chi^{2}$ which for the freeing scale 2 is $\chi^{2}=5.991$, it comes out that the presented sub-hypothesis has been verified. This sub-hypothesis is verified, also, for the level of importance $1 \%=0.01$ since for the freeing scale 2 the standard value of $\chi^{2}$ is 9.210 .

Table 6

\begin{tabular}{|l|l|l|}
\hline Key hypothesis & $\begin{array}{l}\text { The emotional maturity is an indicator that adolescent students have achieved } \\
\text { good success at school }\end{array}$ & Supported \\
\hline Sub-hypothesis H1 & The emotional maturation depends on the age of adolescent students & Supported \\
\hline Sub-hypothesis H2 & The emotional maturation depends on the gender of adolescent students & Rejected \\
\hline Sub-hypothesis H3 & $\begin{array}{l}\text { There is a positive impact as regards emotional maturation and achievement of } \\
\text { success at school }\end{array}$ & Supported \\
\hline Sub-hypothesis H4 & $\begin{array}{l}\text { The emotional maturation and the success of the adolescent students depend on } \\
\text { the age and gender of the adolescent respondents who have been researched }\end{array}$ & Supported \\
\hline
\end{tabular}

\section{Summary}

Based on these empiric researches that covered a sample of 200 pupils (100 students belonged to the 10th class and 100 students belonged to the 13th class), half of them were males and half of them were females, we can ascertain that the key hypothesis has been verified: „, The emotional maturity is an indicator that adolescent students have achieved good success at school". By chi-squared test, also, have been verified sub-hypotheses (auxiliary hypothesis) approved for empiric review of the emotional maturation of adolescent students at the Technical Secondary School,„28 November" in Prishtina. The results from this empiric research into the same sample do not verify sub-hypothesis $\mathrm{H2}$ :,, The emotional maturation depends on the gender of adolescent students ". Thus, this hypothesis is rejected since there is a big difference between theoretical and empiric frequencies.

\section{References}

Bekteshi B. (2005) "Statistika elementare, botim i dytë", Libri shkollor, Prishtinë

Boyle, G. J., Stankov, L. M ,Cattell,R.B. (1995) "Mesaurment and statistical models in the study of personalit and intelligence",New York. Daniel Golman(1995)"Emotional intelligence",1995. 
Dragoti, E.(2005)" Adoleshenti", Albdesign", Tiranë.

Krasniqi, N.(2011)" Ndikimi i pjekurisë emocionale në sukësesin e nxënësve aoleshentë", Punim magjistrature, Tetovë.

Nushi, P.(2002)"Psikologji e përgjithshme l", Libri shkollor, Prishtinë.

Nushi,P.(2014)" Leksikon i psikologjisë", Vëllimi I, ASHAK.

Nushi,P.(2014)" Leksikon i psikologjisë, Vëllimi II", ASHAK.

Orhani, Z.(2011)" Psikologji e emocioneve", Shtëpia botuese "Vllamasi", Tiranë.

Pango,Y."(2005) Psikologji sociale".ILAR, Tiranë. 